\title{
The Effect of Industrialization and Population Growth on Migration
}

\author{
Arini Fitria Mustapita*, Khalikussabir \\ Faculty of Economics and Business, Islamic University of Malang, Malang \\ *AriniMustapita@unisma.ac.id
}

\begin{abstract}
Industry is an important thing in development. It is based on the reasons, industrialization can increase income and prosperity quickly. Industrialization is also a factor that encourages people to migrate. The population prefers to migrate on urban areas which have a greater employment opportunities in the industrial sector. This study aims to determine the effect of industrialization and population growth on internal migration in Malang City. The analytical method is a multiple analysis with Ordinary Least Square (OLS) technique. The results show that the industrialization has no a significant effect on migration, while the population growth has a significant effect on internal migration.
\end{abstract}

Keywords : Industrialization, Migration, Population Growth

\section{INTRODUCTION}

Determination of the industry as the important of development based on reasons that industrialization can increase revenues and prosperity quickly. The development concept is also often associated with the process of industrialization, for its understanding is often considered the same. The industrialization process is an effort to improve people's welfare in the sense of living a more advanced and quality society. This is because the industry is considered to be able to develop faster when compared to the agricultural sector (Arsyad, 1999). In addition, industrialization is also a factor that encourages people to migrate. This is because the population prefers to migrate to urban areas which do have greater employment opportunities in the industrial sector.

One area that shows a relatively high phenomenon of migration is Malang City. Malang City as a city of education, tourism and industry has its own magnet for residents to migrate to Malang City. This is evident in the last five years that the population of Malang City has an increase in population of 50,116 people. It is known that the main contributor to population growth is the migration of people who move from other regions to Malang. Contributions from this migration factor are more significant than population growth from birth. In addition, the economic growth of Malang City reached $5.61 \%$. This means that the city of Malang is above the average economic growth of East Java which is at 5.5\% (BPS, 2014). Malang City is able to contribute to economic growth on the regional scale of East Java and national scale. The biggest contribution given by Malang City is in the industrial and trade sectors. This is what caused Malang City to become one of the destinations for the population to migrate.

Apart from industrialization, population growth is phenomenal and quite worrying for countries in the world. As in 
Indonesia, population growth is a big problem compared to other countries. Indonesia is one country that has a population of approximately 250 million people. This will be a problem when high population growth is not balanced with the level of community welfare, because population growth will affect several aspects of life both economic and social aspects. Other problems caused by rapid population growth include employment problems, employment opportunities that are associated with economic opportunities obtained (Rizal, 2006). In addition, rapid population growth can also cause a population explosion. This is caused by several factors that influence, among others, the death rate, birth rate to migration. One of the actual issues in development in developing countries is Migration. Migration is the movement of people from one region to another, which occurs because of differences in the conditions of the two regions (Martin, 2003).

Indonesian people are more likely to migrate as an option to improve welfare. There are several factors that encourage migrants to migrate and are divided into three groups, including the demand pull factor, supply push and network. The demand pull factor occurs if there is a demand for labor from the destination. The supply push factor occurs if the workforce is no longer possible to get work in its own area, thus encouraging them to migrate to other areas. Network factor, is a factor that can provide information for migrants in making decisions to migrate (Everet S. Lee in Chotib 2000).

In general, the population migrates to urban areas, because urban areas function as centers of economic, social political and cultural activities. Usually the most interesting thing is the development of the population due to migration that follows the economic development of urban areas, this condition ultimately has a cumulative effect, because precisely the economic development that starts from urban areas is the main cause of the arrival of migrants to the city. In addition to migration issues, another problem is the transformation of labor from various sources as evidenced by the experience of developed countries which shows that at the beginning of the development of human resources more concentrated in the agricultural sector. Increased farmer income followed by changes in consumption patterns, especially non agricultural consumption can refer to industrial growth.

\section{Industrialization}

Industry has two meanings, broadly and narrowly understood. In broad terms, industry includes all productive businesses and activities in the field of economics. While narrow understanding, industry or processing industry is an activity that changes a basic item mechanically, chemically, or by hand so that it becomes a semi finished or finished goods.

Industry is an effort to improve the welfare of the population. In addition, industrialization is also inseparable from efforts to improve the quality of human resources and the ability to utilize natural resources optimally. Law No. 5 of 1984 on Industry, the industry is an economic activity which manages raw materials, raw materials, semi-finished goods and finished goods into or goods with a higher value for its use including activities and industrial engineering design. From a geographic point of view, industry as a system is a combination of physical sub systems and human sub systems.

Industrialization is one of the key processes of economic development. In the industrialization process, the industrial sector is made part of the footing that is expected to produce optimal output that can absorb labor as much as possible. This is the desire of every country, so that quite complex economic problems such as poverty and unemployment can be overcome.

\section{Population Growth}

Population growth is a dynamic balance between the forces that increase and 
reduce the population. Population growth is caused by several components, namely : fertility, mortality (mortality), in migration and out migration.

Badan Pusat Statistik (2000) states that population growth in a region or country can be calculated by comparing the initial population (P0) with the number of population in the future $(\mathrm{Pt})$. Problems related to geographical population distribution are uneven distribution or distribution of population. Whereas there is a positive influence of population growth on economic growth where the conditions and progress of the population are very closely related to the growth and development of economic enterprises. Population can be a resource for production factors, on the other hand it can be a target or consumer for the product produced. Population conditions, population data and information will be very useful in calculating how much labor will be absorbed as well as certain qualifications needed and the types of technology that will be used to produce goods or services. knowledge of population structure and socioeconomic conditions in certain regions, will be very useful in calculating how many people can take advantage of opportunities and development outcomes or how wide the market share for a particular business product (Todaro, 2003).

\section{Migration}

The definition of migration is simply a movement activity. While formally, migration is defined as movement of people for the purpose of settling from one place to another that transcends political boundaries / state or administrative limits / boundary of a country. Migration that transcends national borders is called international migration while internal migration is the movement of population that occurs within the boundaries of a country, both between regions or between provinces.

If migration is spatially seen both geographic and administrative boundaries, then there are two types of migration is the movement of local and internal mirasi. Local movements are geographical movements of population but do not cross administrative boundaries, while internal migration crosses administrative boundaries. Internal migration that occurred in Indonesia consists of transmigration and urbanization. Transmigration is a movement of people from one island to another in Indonesia. In this analysis transmigration is the movement of people from one island to another in Indonesia. On the other hand urbanization, which is the movement of people from village to city, generally occurs in other island residents who want to get better jobs on other islands.

$\mathrm{H}_{1}$ : Industrialization and population growth have a simultaneous effect on internal migration in the Malang City

$\mathrm{H}_{2}$ : Industrialization has an effect on internal migration in Malang City

$\mathrm{H}_{3}$ : Population growth has an effect on internal migration in Malang City

\section{METHOD}

This study chose Malang as the research setting since it is one of potential industrial area in East Java. The data used in this research are secondary that obtained from the central bereau of statistic (Badan Pusat Statistik) and other institutions related to these activities. The data were analyzed by Ordinary Least Square (OLS) technique both descriptively and inferentially. In examining the effect of industrialitation and population growth rate on the level of migration in this study using multiple linear regression analysis techniques.

Malang City is the second largest city in East Java after Surabaya. Malang is administratively divided into five districts, in Kedungkandang, District, Sukun, Klojen, Blimbing district, and Lowokwaru District. Here is a diagram of a data distribution industry by district in Malang 


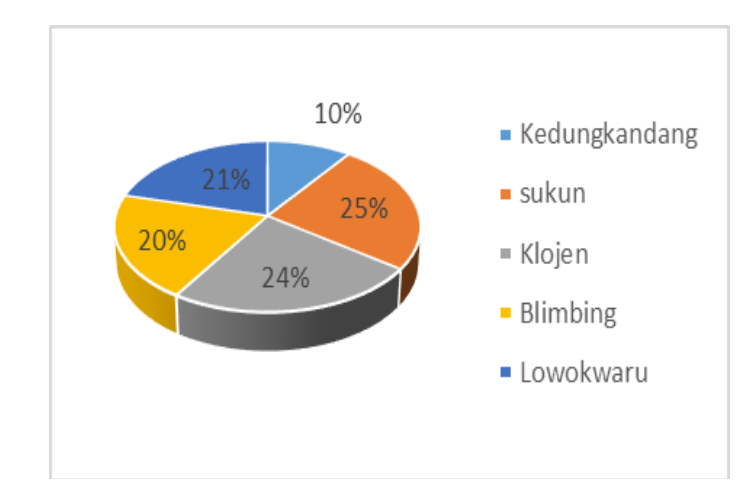

Figure 1. Diagram the Distribution of Industry In Malang City

Data sources: BPS, 2016

From the diagram figure 1, it can be seen that the largest industry distribution is in Klojen sub-district and the smallest industry distribution is in Kedungkandang sub-district.

The indicators of each variable used in this research are: 1) Industrialization is measured by the number of large industries, medium industries and small industries; 2) Population growth measured by the changed number of population based on fertility and mortality, 3) Migration is measured by the number of migration.

\section{RESULT AND DISCUSSION}

Estimation Results The effect of industrialization and population growth on Migration in Malang

Table 1. Regression Result

\begin{tabular}{llll}
\hline Model & R & R Square & $\begin{array}{l}\text { Adjusted } \\
\text { R Square }\end{array}$ \\
1 & $.983^{\mathrm{a}}$ & .967 & .933 \\
\hline \multicolumn{3}{l}{ Data sources: Primary data processed, 2018}
\end{tabular}

From the table 1 of regression result, it is known that there is a correlation level of 0.983 which means that the variables of industrialization and population growth have a very strong correlation to the variable migration. The other result is known that migration $96,7 \%$ can be explained by variables of industrialization and population growth and 3,3\% influenced by other variables outside the model.
Table 2. Uji F

\begin{tabular}{lll}
\hline Model & F & Sig \\
\hline Regression & 29.044 & $.033^{\mathrm{a}}$ \\
Residual & & \\
Total & & \\
\hline
\end{tabular}

Data sources: secondary data processed, 2018

Based on the results of the $\mathrm{F}$ test on table 2 it is known that the results of the significance $\mathrm{F}$ is $0.033(<0.05)$. It means that industrialization and population have a simultaneous effect on the migration. It indicates that model is fit.

Table 3. Uji T

\begin{tabular}{|c|c|c|}
\hline Model & B & Sig \\
\hline (Constant) & -87.297 & .931 \\
\hline Industrialization & 39.934 & .073 \\
\hline $\begin{array}{l}\text { Population } \\
\text { growth }\end{array}$ & .031 & .027 \\
\hline
\end{tabular}

Based on the results of the test on table 3 it is known that the results of the significance of industrialization variable on the migration level is $0.073(>0.05)$. It means that the industrialization variable does not significantly influence the migration variable. Whereas for population growth variable on migration has a significance value of $0.027 \quad(<0.05)$. It means that population growth variable has a significant effect on the migration variable.

From the regression results above it is known that industrialization has a positive and not significant effect on the level of migration in the city of Malang, while population growth has a positive and significant effect on the level of migration in the city of Malang. Industrialization has a positive and insignificant effect on the level of migration. It means that the higher the industrialization, the higher the level of migration in Malang City. But from the partial test, industrialization variables did not significantly affect migration in Malang. This is inversely proportional to the research conducted by (Setyowati, 2011), that industrialization has a significant effect on 
the level of urbanization. One of the reasons is that the industry in Malang City is still not too much compared to other cities around Malang City.

Residents of other cities still think twice to stay in Malang City because the industrial centers are still limited. If the centers industry is still limited, competition between job seekers will be more tighter. The community chooses other cities that offer many industrial centers as an option in finding work. This makes the industrialization does not significantly influence the migration rate in Malang City. However, the lack of industry in Malang City does not make the rate of migration is low. The city of Malang as a city of education makes the majority of migration in Malang City dominated by students or college students who are attending education. Malang City offers a variety of campus options, fresh air and a fairly cheap living cost for college students.

Variable population growth on migration in the city of Malang has a positive and significant relationship. It related with research of Setyowati (2011), when the population growth variable increases, the level of in-migration also increases. Variable population growth also has a significant effect on population growth in Malang City. This happens because increased population growth will make the migration of people in or out also increase. There are many factors that cause this, among others, when population growth increases. The one factors is when population growth increases, the opportunity to obtain employment becomes more tight. If the increasing of competition between workers is not accompanied by the increasing of employment opportunities, it can lead to unemployment which results in the migration of people to areas that have many job opportunities.

\section{Conclution}

Industrialization has a positive and insignificant effect on the level of migration in Malang City. Industrialization has no significant effect on the level of migration because the industry in Malang City is still not too high to attract people to migrate on Malang City.

Population Growth has a positive and significant effect on the level of migration in Malang City. The positive effects indicate that if the population growth increases, the rate of migration in Malang City also increases. The one factors is when population growth increases, the opportunity to obtain employment becomes more tight and it can make the people choice to go out of Malang City.

Based on that result, the government should make various policies that are able to encourage the development of industrial centers in Malang City.

\section{REFERENCES}

Badan Pusat Statistik. 2014. Kota Malang dalam Angka. Malang: Badan Pusat Stastistik Kabupaten Malang.

Guntoro, Dibyo Waskito. 2016. Analisis Faktor-Faktor yang Mempengaruhi Penduduk Melakukan Migrasi Internal di Indonesia. Jogjakarta. Jawa Tengah

Karib, Abdul MS. (2012). Analisis Pengaruh Produksi, Investasi dan Unit Usaha Terhadap Penyerapan Tenaga Kerja Pada Sektor Industri Sumatera Barat. Jurnal Manajemen Dan Kewirausahaan, Volume 3, Nomor 3, September 2012 Issn : 2086-5031. Universitas Andalas. Padang.

Kurniati, Ani. 2007. Industrialisasi Dan Migrasi Tenaga Kerja Sektor Di Kota Cilacap (Studi Kasus: Industri BesarSedang Di Kota Cilacap). Cilacap. Jawa Barat

Kuncoro, Mudrajad. 2009. Metode Riset Untuk Bisnis dan Ekonomi. Jakarta : Erlangga

Martin. P. L. 2003. Sustainable Migration Polines in a Globalizing World. International Institute for Labor Studies. Geneva.

Maryanti, Tatik. 2010. Pengaruh Industrialisasi Terhadap Migrasi Per 
Propinsi di Indonesia pada tahun 2010”. Jakarta

Massey, Douglas S., Joaquin Arango, Graeme Hugo, Ali Kouaouci, Adela Pellegrino, and J. Edward Taylor. 1998. Worlds in Motion: Understanding International Migration at the End of the Millennium. New York. Oxford University Press.

Muhtamil, 2017. Pengaruh Perkembangan Industri Terhadap Penyerapan Tenaga Kerja di Provinsi Jambi. Jurnal Perspektif Pembiayaan dan Pembangunan Daerah Vol. 4 No. 3, Januari - Maret 2017

Ruhs, Martin. 2003. Temporary foreign worker programmes: Policies, adverse consequences, and the need to make them work. Perspectives on Labour Migration, No. 6. Geneva. International Labour Office.

Setyowati. 2011. Pengaruh Industrialisasi dan Pertumbuhan Penduduk terhadap Proses Urbanisasi di Jawa Tengah. Jawa Tengah

Yusni Maulida, 2013. Pengaruh Tingkat Upah Terhadap Migrasi Masuk Di Kota Pekanbaru. Jurnal Ekonomi. Volume 21, Nomor 2 Juni 2013

Syaadah, Nilatus. 2014. Analisis Dampak Pertambahan Penduduk Terhadap Penyerapan Angkatan Kerja. Semarang. Jawa Tengah 